\title{
Effect of Chlorpyrifos 50\% + Cypermethrin 5\% EC on Eisenia fetida Exposed in Coco Peat and Sphagnum Peat
}

\author{
A. Rajini*† and K. Revathy** \\ *Department of Ecotoxicology, International Institute of Biotechnology and Toxicology, Padappai-601301, \\ Kancheepuram, Tamil Nadu, India \\ **Meenakshi Academy of Higher Education and Research, K. K Nagar, Chennai-600 078, Tamil Nadu, India \\ $\dagger$ Corresponding author: A. Rajini; rajitox@gmail.com
}

\section{Nat. Env. \& Poll. Tech.} Website: www.neptjournal.com

Received: $27-01-2020$

Revised: $17-02-2020$

Accepted: 15-04-2020

Key Words:

Chlorpyrifos

Cypermethrin

Eisenia fetida

Sphagnum peat

\section{ABSTRACT}

Toxicity effect of Chlorpyrifos 50\% + Cypermethrin 5\% EC to terrestrial invertebrate Eisenia fetida in two different sphagnum peat substituted soil was assessed. Artificial soil substrate for earthworm toxicity test comprises of $70 \%$ sand, $20 \%$ clay and $10 \%$ sphagnum peat. In this study, coco peat was used as an alternative substitute for sphagnum peat. The $\mathrm{LC}_{50}$ was $83.7 \mathrm{mg} / \mathrm{kg}$ for coco peat and $76.3 \mathrm{mg} /$ $\mathrm{kg}$ for sphagnum peat soil. No significant difference was observed in mortality and biomass between the two soil substrates, but a significant difference was observed in the reproduction. Based on the observations, it is concluded that coco peat can also be used as an alternative to sphagnum peat in toxicity studies.

\section{INTRODUCTION}

Organophosphorus pesticide chlorpyrifos and pyrethroid cypermethrin are used extensively in individual or combination for agricultural and public health pest control. Pesticides reach the soil by leaching or from direct addition for controlling pests. The bioavailability of the pesticide may affect the exposed organisms leading to mortality or reduced population due to its effect on reproduction. Soil invertebrate earthworm is extensively used in the toxicity testing for assessing the damage caused to the soil due to the indiscriminate usage of pesticides. Chlorpyrifos has high application rate for termite treatments hence found in freshwater sediments. It exceeds Stockholm convention criteria for bioaccumulation. It is transported to long ranges and has been found consistently in arctic ice, snow, fog, air, seawater, lake sediments and fishes. It is also considered as an endocrine disrupter with anti-androgenic and estrogenic properties. Cypermethrin is a contact insecticide. Mali (2019) has stated that pyrethroid binds with soil components and thereby leaches into the groundwater as residues, which are harmful to the ecosystem. Pyrethroid molecule may bind to sex hormone and chronic exposure may result in disturbances in hormonal effects

In laboratories, pesticide risk to earthworm is assessed in artificial soil prepared based on guidelines and the obtained data is used for regulatory risk assessment. For assessing the toxicity effect, artificial soil is prepared in the laboratory with sphagnum peat. Sphagnum peat in the artificial soil is an organic amendment as per OECD (1984), ISO (1993) and ISO (1998) guidelines. It consists of about $10 \%$ and other soil ingredients are $70 \%$ sand, $20 \%$ clay and $0-1 \%$ calcium carbonate. Use of peat moss is decreasing due to its high cost and environmental considerations (Jung \& Yang 2014). Jackie (2015) has reported that peat moss used in the United States comes from remote bogs in Canada and there is considerable controversy surrounding the mining of peat moss. As the mining is regulated, only about $0.02 \%$ is available for harvest. International Peat Society points out that the mining process releases massive amounts of carbon into the atmosphere, and bogs continue to exhale carbon long after the mining concludes. Despite, manufacturers of peat moss claim that the bogs can be restored, the delicate community that inhabits the bog cannot be quickly re-established. Though peat moss is a renewable resource, it can take hundreds to thousands of years to form. Peat bogs purify fresh air and mitigate flood damage. Carbon dioxide is also preserved and trapped in the moss, $10 \%$ of all fixed carbon is stored in it but released into the air when mined.

Cocos nucifera is largely cultivated in Philippines, Indonesia, India and Sri Lanka and India has emerged as a premier 
coconut producer with its annual production of about 12 billion (Jeyaseeli et al. 2010). Coco peat is a by-product of the coconut processing industry and it is available abundantly in tropical countries. Coco peat contains lignin, cellulose and hemicellulose (Yew \& Wee 2014). Recycling of organic matter helps in the improvement of soil physical, chemical and biological properties (Kamalraj et al. 2017).

Very few studies have been conducted for replacement of sphagnum peat in artificial soil. Chlorpyrifos $50 \%+$ Cypermethrin 5\% EC toxicity and its reproduction effect to earthworm Eisenia fetida were assessed with coco peat as an alternative substitute to sphagnum peat in the present study.

\section{MATERIALS AND METHODS}

Chlorpyrifos 50\% and Cypermethrin 5\% EC was purchased from commercial market. Earthworm, Eisenia fetida was obtained from the culture maintained at the Department of Ecotoxicology, IIBAT. Composted coco peat was procured from Varsha Enterprises, Bangalore and Sphagnum peat was imported from Gramoflor GmbH \& Co, Germany as solid blocks. Peat procured was shade dried and pulverised by grinding machine and particle size of $<2 \mathrm{~mm}$ was obtained using sieves. Kaolin clay was purchased from Romac India Ltd., Chennai and sand with a particle size of 50 to 200 microns was used.

\section{Exposure of Earthworms in Artificial Soils}

The artificial soils were prepared as per the guideline OECD (1984) for sphagnum and composted coco peat, separately. Artificial soil was prepared by mixing $70 \%$ sand, $20 \%$ clay and $10 \%$ peat. They were added in a laboratory homogeniser, homogenised for 20 minutes and stored in airtight containers at room temperature. Maximum water holding capacity was performed by the method specified in the guideline (OECD 2004) with slight modifications. About $175 \mathrm{~mL}$ of deionised water was used to moisten the soil for earthworm survival.

Glass beakers of 2 L capacity were filled with approximately $500 \mathrm{~g}$ of artificial soil. Earthworms were exposed to pesticide concentrations of 12.3, 22.1, 39.7, 71.4, $128.6,231.5,416.6$ and $750 \mathrm{mg} / \mathrm{kg}$ of soil, a control group was also maintained. Pesticide concentrations were applied to the artificial soil and homogenised using a laboratory mixer and moistened with water. Earthworms of about 4-6 months old with a wet weight in the range of 260 to $450 \mathrm{mg} /$ worm including gut contents with well-developed clitellum were acclimatised one day prior in the respective artificial soils. Shade dried and powdered cow manure was added on the top of the soil as food and feed consumption was observed visually and fresh feed was added once weekly. Four replications for each concentration and eight replications for control were maintained with ten earthworms. The glass beakers were maintained in the test room with a temperature of $20 \pm 2^{\circ} \mathrm{C}$ and light intensity range was kept at $400-800$ lux. The earthworms were exposed for 28 days to the pesticide mixed soil. After 28 days, they were sorted from the soil and observed for mortality. The live earthworms were weighed and disposed of. After removal of the adult earthworms on day 28 , five gram of cow manure was mixed into the artificial soil to feed the juveniles in the container. The soils were maintained in the same test conditions for an additional 28 days and for reproduction assessment the soil from the beakers was transferred to a tray and kept in a water bath at $50^{\circ} \mathrm{C}$. The juveniles in each beaker were sorted and counted manually.

\section{RESULTS}

No mortality was observed in control and concentrations of $12.3,22.1,39.7 \mathrm{mg} / \mathrm{kg}$ in the soil containing coco peat and sphagnum peat, mortality was observed in the concentration of $71.4,128.6,231.5,416.6$ and $750 \mathrm{mg} / \mathrm{kg}$ soil in coco peat and sphagnum peat containing soil. In 39.7 and $71.4 \mathrm{mg} / \mathrm{kg}$ soil inability to burrow into the soil was observed in both artificial soils. No-observed effect concentrations related to mortality were found to be $39.7 \mathrm{mg} / \mathrm{kg}$ soil, for both the soils (Fisher's exact test). No observed effect concentration related to biomass was found to be 71.4 and $128.6 \mathrm{mg} / \mathrm{kg}$ for coco peat and sphagnum peat soils (Dunn's test). $\mathrm{LC}_{50}$ of Chlorpyrifos $50 \%+$ Cypermethrin $5 \%$ EC at 28 days after exposure was observed to be $83.7 \mathrm{mg} / \mathrm{kg}$ for coco peat soil and $76.3 \mathrm{mg} / \mathrm{kg}$ soil for Sphagnum peat soil and $\mathrm{EC}_{50}$ (Effective concentration based on reproduction) was 60.01 $\mathrm{mg} / \mathrm{kg}$ coco peat soil and $45.48 \mathrm{mg} / \mathrm{kg}$ for sphagnum peat soil are summarised in Table 1.

The overall comparison at all the dose-response level on mortality between the soils was not significant (Two-factorial

Table 1: Comparison of mortality, biomass change and juveniles exposure to Chlorpyrifos 50\% + Cypermethrin 5\% EC in coco peat and sphagnum peat soils.

\begin{tabular}{|c|c|c|}
\hline End points & Coco peat & Sphagnum peat \\
\hline $\begin{array}{l}\text { NOEC }(\mathrm{mg} / \mathrm{kg}) \\
\text { Mortality }(\%)^{\#}\end{array}$ & 39.7 & 39.7 \\
\hline $\begin{array}{l}\text { NOEC }(\mathrm{mg} / \mathrm{kg}) \\
\text { Biomass change }(\%)^{\# \#}\end{array}$ & 71.4 & 128.6 \\
\hline $\begin{array}{l}\text { NOEC }(\mathrm{mg} / \mathrm{kg}) \\
\text { Reproduction }(\%)^{\# \#}\end{array}$ & 22.1 & $<12.3$ \\
\hline $\begin{array}{l}\mathrm{LC}_{50}(\mathrm{mg} / \mathrm{kg})^{\$} \\
\text { (Fiducial limits) }^{\text {(Fimal }}\end{array}$ & $\begin{array}{l}83.7 \\
(76.2-92.1)\end{array}$ & $\begin{array}{l}76.3 \\
(68.9-84.2)\end{array}$ \\
\hline $\begin{array}{l}\mathrm{EC}_{50}(\mathrm{mg} / \mathrm{kg})^{@} \\
\text { (Fiducial limits) }\end{array}$ & $\begin{array}{l}60.01 \\
(31.48-88.55)\end{array}$ & $\begin{array}{l}45.48 \\
(42.36-48.83) \\
\end{array}$ \\
\hline
\end{tabular}

NOEC-No-Observed Effect Concentration, Fisher's exact test", Dunn's for NOEC ${ }^{\# \#,} 3$ Probit Analysis $\$$, OECD Model 2 by MARQUARDT ${ }^{\circledR}$ 
ANOVA, $\mathrm{p}=0.05)$. The biomass of adult earthworms in the control group had an increase in both the controls of coco peat soil and sphagnum peat soil. Significant biomass change from control was observed in the concentration of 128.6 and $71.4 \mathrm{mg} / \mathrm{kg}$ soil in coco peat and sphagnum peat soils and are summarised in Table 2.

The overall dose-response biomass change for both the soils was not significant (Two-factorial ANOVA, $\mathrm{p}=0.05$ ). The mean number of juveniles observed in all the concen- trations ranged from 0 to 60.25 and 0 to 76.0 in coco peat and sphagnum peat treated soils. The significant effect on reproduction was observed at $39.7 \mathrm{mg} / \mathrm{kg}$ soil for coco peat and $12.3 \mathrm{mg} / \mathrm{kg}$ soil sphagnum peat soil and are summarised in Table 3. Statistical analyses were performed using ECOSTAT software with SAS.

\section{DISCUSSION}

Pesticides have an impact on the physiology and behaviour

Table 2: Comparison of mortality and biomass change due to pesticide exposure in coco peat and sphagnum peat soils.

\begin{tabular}{|c|c|c|c|c|}
\hline \multirow{2}{*}{$\begin{array}{l}\text { Concentration } \\
(\mathrm{mg} / \mathrm{kg})\end{array}$} & \multicolumn{2}{|c|}{ Mortality $(\%)^{\#}$} & \multicolumn{2}{|c|}{ Biomass change $(\%)^{\# \#}$} \\
\hline & COPS & SPPS & COPS & SPPS \\
\hline Control & 0.0 & 0.0 & $\begin{array}{l}+47.95 \\
(8.16)\end{array}$ & $\begin{array}{l}+29.27 \\
(13.72)\end{array}$ \\
\hline 12.3 & $0.0 \mathrm{n} . \mathrm{s}$ & $0.0 \mathrm{n} . \mathrm{s}$ & $\begin{array}{l}+49.43 \text { n.s } \\
(1.00)\end{array}$ & $\begin{array}{l}+33.59 \text { n.s } \\
(4.96)\end{array}$ \\
\hline 22.1 & $0.0 \mathrm{n} . \mathrm{s}$ & $0.0 \mathrm{n.s}$ & $\begin{array}{l}+54.69 \mathrm{n} . \mathrm{s} \\
(3.52)\end{array}$ & $\begin{array}{l}+41.80 \mathrm{n} . \mathrm{s} \\
(5.69)\end{array}$ \\
\hline 39.7 & $0.0 \mathrm{n} . \mathrm{s}$ & $0.0 \mathrm{n} . \mathrm{s}$ & $\begin{array}{l}+46.92 \mathrm{n} . \mathrm{s} \\
(6.44)\end{array}$ & $\begin{array}{l}+24.51 \mathrm{n} . \mathrm{s} \\
(13.71)\end{array}$ \\
\hline 71.4 & $\begin{array}{l}27.50^{*} \\
(15.0)\end{array}$ & $\begin{array}{l}45.00 * \\
(12.91)\end{array}$ & $\begin{array}{l}+38.51 \mathrm{n} . \mathrm{s} \\
(3.37)\end{array}$ & $\begin{array}{l}+17.45 * \\
(4.97)\end{array}$ \\
\hline 128.6 & $\begin{array}{l}95.00 * \\
(5.77)\end{array}$ & $\begin{array}{l}95.00^{*} \\
(5.77)\end{array}$ & $\begin{array}{l}-53.90 * \\
(53.58)\end{array}$ & $\begin{array}{l}-54.05 * \\
(53.57)\end{array}$ \\
\hline 231.5 & $100^{*}$ & $100 *$ & $-100 *$ & $-100 *$ \\
\hline 416.6 & $100 *$ & $100 *$ & $-100 *$ & $-100^{*}$ \\
\hline 750 & $100 *$ & $100 *$ & $-100 *$ & $-100^{*}$ \\
\hline \multirow[t]{2}{*}{ Statistical comparisons between soil ${ }^{\# \# \#}$} & P-value & & & \\
\hline & $0.0052^{*}$ & & $0.7211 \mathrm{n} . \mathrm{s}$ & \\
\hline
\end{tabular}

COPS - Coco peat soil; SPPS - Sphagnum peat soil; Mean of four replications; Figures in parentheses are Standard Deviation; n.s. = not significantly

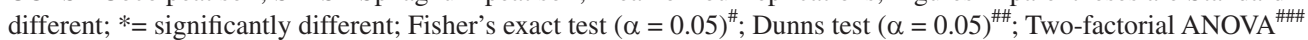

Table 3: Comparison of reproduction effect of the pesticide in coco peat and sphagnum peat soils.

\begin{tabular}{|c|c|c|c|c|}
\hline \multirow{2}{*}{$\begin{array}{l}\text { Concentration } \\
(\mathrm{mg} / \mathrm{kg})\end{array}$} & \multicolumn{2}{|c|}{ Juveniles (No.) $^{\#}$} & \multicolumn{2}{|c|}{ Reduction over control (\%) } \\
\hline & COPS & SPPS & COPS & SPPS \\
\hline Control & $\begin{array}{l}58.63 \\
(6.16)\end{array}$ & $\begin{array}{l}101.75 \\
(11.06)\end{array}$ & NA & NA \\
\hline 12.3 & $\begin{array}{l}60.25 \mathrm{n} . \mathrm{s} \\
(4.79)\end{array}$ & $\begin{array}{l}75.75^{*} \\
(12.45)\end{array}$ & 46.27 & 25.55 \\
\hline 22.1 & $\begin{array}{l}51.50 \mathrm{n} . \mathrm{s} \\
(5.80)\end{array}$ & $\begin{array}{l}76.00 * \\
(6.38)\end{array}$ & 12.16 & 25.31 \\
\hline 39.7 & $\begin{array}{l}31.50^{*} \\
(3.11)\end{array}$ & $\begin{array}{l}61.75^{*} \\
(5.56)\end{array}$ & -2.76 & 39.31 \\
\hline 71.4 & $\begin{array}{l}8.50 * \\
(2.38)\end{array}$ & $\begin{array}{l}6.50 * \\
(1.73)\end{array}$ & 85.50 & 93.61 \\
\hline 128.6 & 0 & $0 *$ & 100 & 100 \\
\hline 231.5 & 0 & $0^{*}$ & 100 & 100 \\
\hline 416.6 & 0 & $0^{*}$ & 100 & 100 \\
\hline 750 & 0 & $0 *$ & 100 & 100 \\
\hline Statistical comparisons between soil ${ }^{\# \#}$ & $\begin{array}{l}\mathrm{P} \text { value } \\
<0.0001 *\end{array}$ & & - & \\
\hline
\end{tabular}

Mean of four replications; Figures in parentheses are standard deviation; n.s. = not significantly different; * significantly different; Trend test $($ Jonckheere-Terpstra) $(\alpha=0.05)^{\#}$; Two-factorial ANOVA ${ }^{\#}$ 
of earthworms; the worms have developed mechanisms to detoxify themselves and spend a lot of energy for it, hence they do not reach the normal size. They are less successful at reproducing because they spend their energy on ridding themselves of the pesticides (Givaudan et al. 2014). Growth inhibition and reduction in biomass is an indicator of stress. Pesticide affects the energy dynamics and ultimately inhibit the growth and weight of the tested organisms. It has been reported that deltamethrin inhibited growth, and is correlated with the worm's strategy to reduce food intake to avoid the toxins (Mohamed et al. 2013). Avoidance of soils treated with cypermethrin was studied as a bioindicator in Eisenia andrei and earthworms were found in the untreated section of the soil (Sousa 2011). Zhou (2008) studied the effect of cypermethrin chronic exposure and observed that toxicity significantly increased to juveniles than adult earthworms and also growth and reproduction were severely affected. Wang et al. (2012) reported enzyme and cellulose activity of Eisenia fetida was inhibited by treatment with chlorpyrifos. Zhou et al. (2011) stated that pesticide mixture toxicity is not known since the toxicity data obtained are exclusively from individual pesticide; this may mislead the ecological risk of pesticides. Growth and reproduction of earthworms exposed to pesticides are useful bioindicators of soil pollution.

Peat is an organic material which plays a major role to determine toxicity level in earthworm toxicity testing. Fermented coir pith has been recommended as a composition of artificial soil and coir pith is a suitable alternative to Sphagnum peat moss for the composition of artificial soil modified for tropical regions (Abbiramy et al. 2012). De Silva et al. (2009) studied the suitability of coco peat, paddy husk and saw-dust as alternatives to sphagnum peat in the artificial soil for performing ecotoxicity studies and recommend the suitability of coco peat as an alternative to sphagnum peat. Water holding capacity of sphagnum peat was significantly higher than that of coco peat. Moisture content varied of coco and sphagnum peat was 30.07 to $32.66 \%$ and 32.81 to $37.76 \%$, respectively. Total organic matter plays an important role to predict the biological response of earthworms and essential elements are higher in coco peat. Abbiramy et al. (2012) also observed similar physico-chemical characteristics in the two peat samples and it can be correlated with the obtained current results. Tiwari et al. (2019) indicated a potential risk of chlorpyrifos, cypermethrin individual pesticide and its combination. It had a synergistic cumulative impact in a dose-dependent manner during exposure to earthworms.

The present experimental results validate the use of coco peat as an alternative to sphagnum peat in the artificial soil prepared for toxicity studies.

\section{CONCLUSION}

From the results, it is concluded that the combination pesticide, Chlorpyrifos 50\% + Cypermethrin 5\% EC had a profound effect on the biomass and reproduction of the exposed earthworms in both the soils containing the coco and sphagnum peat and coco peat can be used as an alternative substitute of sphagnum peat.

\section{ACKNOWLEDGEMENT}

The author is thankful to IIBAT and Department of Ecotoxicology for providing the research facility.

\section{REFERENCES}

Abbiramy, K.S., Ronald Ross, P., Thenmozhi, P., Muthulingam, M., Paramanandham, J. and Manoharan, V. 2012. The validation of modified tropical artificial soil by ecotoxicological studies on Eisenia foetida. International Journal of Development Research, 2(5): 1051-1056.

De Silva, P.M.C.S. and Van Gestel, C.A.M. 2009. Development of an alternative artificial soil for earthworm toxicity testing in tropical countries. Appl. Soil Ecol., 43(2-3): 170-174. doi:10.1016/ j.ap soil.2009.07.002.

Garcia, M., Scheffczyk, A., Garcia, T. and Rombke, J. 2011. The effects of the insecticide lambda-Cyhalothrin on the earthworm Eisenia fetida under experimental conditions of tropical and temperate regions. Environ. Pollut., 159: 398-400.

Givaudan, N., Wiegand, C., Le Bot, B., Renault, D., Pallois, F., Llopis, S. and Binet, F. 2014. Acclimation of earthworms to chemicals in anthropogenic landscapes, physiological mechanisms and soil ecological implications. Soil Biology and Biochemistry, 73: 49-58. doi: 10.1016/j.soilbio.01.032.

ISO 1993. Soil quality-effects of pollutants on earthworms (Eisenia fetida), Part 1: Determination of acute toxicity using artificial soil substrate. ISO 11268-1. International Organization for Standardization, Geneva, Switzerland.

ISO 1998. Soil quality-effects of pollutants on earthworms (Eisenia fetida), Part 2: Determination of effects on reproduction. ISO 11268-2. International Organization for Standardization, Geneva, Switzerland.

Jackie, Carroll 2015. Peat Moss and Gardening - Information about Sphagnum Peat Moss http://www.gardeningknowhow.com/gardenhow-to/soil-fertilizer/peatmoss information.html.

Jeyaseeli, D.M. and Raj, S.P. 2010. Chemical characteristics of coir pith as a function of its particle size to be used as soilless medium. Ecoscan, 4(2\&3): 163-169.

Jung, J.Y. and Yang, J.K. 2014. The suitability evaluation of lignocellulosic substrate as growing media substitute. African Journal of Biotechnology, 13(14): 1541-1549.

Kamalraj, R., Nandhivarman, M., Pynkhlainbor Thongni, Pradheeps, M. and Poyyamoli, G. 2017. Utilization of agrowastes for vermicomposting and its impact on growth and reproduction of selected earthworm species in Puducherry, India. Nature Environment and Pollution Technology.16(4): 1125-1133.

Mali, G.V. 2019. Toxicological study of bifenthrin and its metabolites on earthworm (Eisenia fetida). Nature Environment and Pollution Technology, 18(4): 1387-1391.

Mohamed, E. I. Badawy, Anter Kenawy and Ahmed, F. El-Aswad 2013. Toxicity assessment of buprofezin, lufenuron, and triflumuron to the earthworm Aporrectodea caliginosa. International Journal of Zoology, 2013:174523. doi: 10.1155/2013/174523. 
OECD 1984. Guideline for Testing of Chemicals No. 207: Earthworm Acute Toxicity Test Organization for Economic Co-Operation and Development, Paris, France.

OECD 2004. Guideline for Testing of Chemicals No. 222: Earthworm Reproduction Test (Eisenia fetida/andrei). Organization for Economic Co-Operation and Development, Paris, France.

Sousa, A.P.A.D. and Andréa, M.M.D. 2011. Earthworm (Eisenia andrei) avoidance of soils treated with cypermethrin. Sensors, 11(12): 1105611063.

Tiwari, R.K., Singh, S. and Pandey, R.S. 2019. Assessment of acute toxicity and biochemical responses to chlorpyrifos, cypermethrin and their combination exposed earthworm, Eudrilus eugeniae. Toxicology Reports, 6: 288-297.
Wang, J. H., Zhu, L.S., Liu, W., Wang, J. and Xie, H. 2012. Biochemical responses of earthworm (Eisenia foetida) to the pesticides chlorpyrifos and fenvalerate. Toxicology Mechanisms and Methods, 22(3): 236-241.

Yew, B.S. and Wee F.H. 2014. Agricultural waste based-coco peat microwave absorber. International Journal of Engineering Sciences \& Emerging Technologies, 7(2): 547-554.

Zhou, S., Changqun, D., Xuehua,W., Michelle, W., Zefen, Y. and Hui, F. 2008. Assessing cypermethrin-contaminated soil with three different earthworm test methods. Journal of Environmental Sciences, 20: 1381-1385.

Zhou, S., Duan, C., Michelle, W.H.G., Yang, F. and Wang, X. 2011. Individual and combined toxic effects of cypermethrin and chlorpyrifos on earthworm. Journal of Environmental Sciences, 23(4): 676-680. 